Inequality and interconnectivity : Urban spaces of justice in Mexico

\author{
Nygren, Anja Kaarina
}

2018-02

Nygren, A K 2018, ' Inequality and interconnectivity : Urban spaces of justice in Mexico ' , Geoforum , vol. 89 , pp. 145-154 . https://doi.org/10.1016/j.geoforum.2017.06.015

http://hdl.handle.net/10138/303509

https://doi.org/10.1016/j.geoforum.2017.06.015

acceptedVersion

Downloaded from Helda, University of Helsinki institutional repository.

This is an electronic reprint of the original article.

This reprint may differ from the original in pagination and typographic detail.

Please cite the original version. 


\title{
INEQUALITY AND INTERCONNECTVITY: \\ URBAN SPACES OF JUSTICE IN MEXICO
}

\author{
Anja Nygren \\ University of Helsinki, Finland
}

\begin{abstract}
Cities in different parts of the world are going through intensive transformations based on institutional efforts to govern urban spaces and populations in the face of global environmental change and neoliberalization of governance. This essay examines inequalities and interconnectivities in urban governance and justice, drawing on a case-study of three, socially-differentiated sectors of the city of Villahermosa, Mexico, between 2011 and 2016. My analysis contributes to a multi-dimensional approach towards justice, and the cognate fields of right to the city, and segregation and inequality, that encompasses: (1) (re)distribution of residents' exposure to risks and access to services; (2) recognition of the causes and consequences of risks and vulnerabilities; (3) fields of representation available for different residents; and (4) residents' capabilities to recover from disasters and achieve everyday well-being within the existing urban governance and service provision structures. Instead of conceptualizing segregated cities as composed of isolated worlds, I argue that it is only possible to understand how the prevailing forms of governance produce multifaceted inequalities through a relational analysis of how residents from different parts of the city interact with the authorities and with each other. The study shows how residents' tactics to accommodate, reconfigure and contest institutional endeavors to place them in hierarchical positions link to their differentiated ways of constructing urban space.
\end{abstract}

Keywords: cities, governance, inequality, justice, Mexico, social differentiation 


\section{Introduction}

'Que triste se oye la lluvia, en los techos de cartón...'

Los Cuaracuao

Cities all over the world are undergoing socio-spatial transformation as the result of institutional efforts to regulate urban spaces and populations in the face of global environmental change and neoliberalization of governance. These procedures transform urban areas and their inhabitants in segmented, yet interlinked ways (Ghertner 2012). Drawing on a study conducted between 2011 and 2016, I examine the interplay of inequalities and interconnectivities in urban governance and justice in the city of Villahermosa, Tabasco, southeastern Mexico. Analysis demonstrates that the neoliberal forms of governance, relying increasingly on public-private partnerships and civic self-governance (Müller 2016, Nygren 2016, Tonkiss 2013), produce multifaceted injustices in terms of the residents' exposure to risks and access to services within socially segregated cities. It also draws attention to how residents' tactics to accommodate, reconfigure and contest institutional endeavors to place them in hierarchical positions relate with their socially differentiated ways of producing urban space and claiming the right to city.

The study is based on an ethnographic analysis of three socio-economically different sectors of Villahermosa: 1) Tabasco 2000, a high-income residential area; 2) El Guayabal, a middle-income neighborhood; and 3) Gaviotas Sur, a low-income, informal settlement and an ambulatory trade area. In 2007, Villahermosa suffered a catastrophic flood, during which $62 \%$ of the city was inundated and damages were calculated at US\$ 3 billion, equivalent to $30 \%$ of the state's gross domestic product (CEPAL 2008). Since then Villahermosa has suffered annually from serious flooding.

Recently, justice approaches have become important perspectives when examining concerns and claims related to governance, inequality, social segregation, right to the city and different kinds of grievances (Attoh 2011, Fraser 2009, Nygren 2014, Schlosberg 2013, Walker 2012, Wayessa and Nygren 2016). Conventionally, justice has been considered merely as a framework that highlights 
socio-spatial distribution of benefits and burdens among human populations. In contrast, this study contributes towards a multi-dimensional approach to justice that encompasses: (1) socio-spatial (re)distribution of residents' exposure to risks and access to services; (2) cultural recognition of risks and vulnerabilities and their causes and consequences; (3) fields of political representation available to different residential groups; and (4) residents' capabilities to recover from disasters and achieve everyday well-being within the prevailing governance structures. Special attention will be paid to how residents structure their relationships with the authorities and with each other, and how they make sense of their experiences of governance and (in)justice.

To understand justice-related inequalities in socially segregated cities requires detailed empirical analysis. This is especially true in many Latin American, African and Asian cities, where large numbers of people live in substandard settlements with inadequate amenities, while urban elites isolate themselves in gated communities with separate water, sanitation and security services. However, instead of conceptualizing segregated cities as composed of unconnected worlds, I argue that only through a relational analysis of how people from different parts of the city interact with the authorities, and with each other, is it possible to understand how the prevailing forms of governance produce multifaceted injustices (Centner 2012, Cosacov and Perelman 2015).

Compared to the rich research on social segregation in Latin America, combined analyses of people's exposure to environmental risks and access to services are scarce. Furthermore, most of the studies that exist focus on marginal settlements, rather than on relational analyses of affluent, middleclass and poor neighborhoods. Based on the view that a relational approach to justice is difficult to develop without an examination of the interactions between different residential groups, this study aims to redress that lacuna. By building on scholarship in fields of justice, urban governance, right to the city and segregation and inequality, this study seeks to contribute to analytical understanding of multi-dimensionality of justice in segregated cities under conditions of neoliberal governance.

The following section presents a theoretical approach to justice that addresses the dimensions of redistribution, recognition, representation and recovery. The third section explains the context and 
the methods of the study, while the fourth examines the distribution of risks and services in a socially fragmented city. This is followed by analysis of how residents' exposure to risks and access to services are linked to recognition, leading into exploration of the representational forums available for different residential groups. The second to last section examines how residents' capabilities to recover from calamity and reconfigure the meanings of everyday life relate with loci of socioeconomic status, before a concluding section on the (re)production and contestation of governance and (in)justice in socially segregated cities.

\section{A multi-dimensional approach to justice}

Most of the earlier research on justice has focused on the (re)distribution of benefits and burdens among human populations, given the fact that differentiated distribution of resources is at the core of many inequalities. Researchers have shown how risks associated with waste and hazardous industries have a spatial expression related to race, poverty and other forms of marginalization (Bullard et al. 2009). Recently, research on (re)distribution as an element of justice has broadened to investigate amenity-related issues, such as access to water and sanitation services.

Closely linked to socio-spatial distribution of goods and bads is the dimension of justice as it operates through recognition, with a focus on how cultural categories, rooted in status hierarchies, underpin the prevailing distribution of benefits and burdens (Fraser 2009, Walker 2012). At the core of (mis)recognition lie the frames of governance that devalue some people and places in comparison to others. Such frames often explain why hazardous industries and other unwanted land uses are concentrated in particular areas and why maintenance services tend to neglect certain neighborhoods whilst protecting quality of life in others. Assumptions that people in certain areas are not interested in taking care of their living sphere affect where institutional efforts to maintain environmental safety and societal security are deployed and where they are not. Authorities and the media play significant roles in framing public opinion on how different social groups should live, thereby shaping common- 
sense conceptions of social differentiation (Auyero and Swistun 2009, Hilgers 2012). As Ghertner (2011: 160) notes, the authorities often use a set of attributes, such as income level and social status, for parsing the city-space into settlements of discrete residential groups considered to differ essentially from each other in their appearance and in their need for institutional control and care.

Current theories of justice also emphasize aspects of political representation in terms of who is engaged in urban planning, and who has a voice in policy-making and public deliberation. Misrepresentation occurs when political boundaries are drawn in ways that deny some people participation in decisions that determine their lives. However, celebrating participation for its own sake - as if local involvement automatically indicates fair representation, or civic contestation inherently leads to emancipation - is analytically simplistic, due to the fact that representational justice also requires legitimate decision-making and the capacity to make binding decisions. Furthermore, recent studies have called for attention to decision-making across diverse expert and lay spaces, as negotiations over governance and justice often traverse multiple arenas: some formal, some informal, some mainstream and some subaltern (Fraser 2008, Müller 2016). For an enhanced understanding of representational justice, it is crucial to analyze different actors' views of who should be entitled to claim justice, through which forms, and how such claims should be redressed.

When examining grievances related to hazards, the justice of recovery becomes another crucial dimension. Herein the question is not so much what kinds of capabilities individuals command, but how communities are able to recuperate collectively (Schlosberg 2013). Recoveryrelated approaches to justice highlight the socially differentiated opportunities people have of taking command of their lives and attaining social fulfillment, conceptualizing well-being not only as 'living well', but as 'living well together' (Wayessa and Nygren 2016: 4). Recently, scholars emphasizing the recovery aspects of justice have called for detailed analyses of how institutional power relationships shape people's abilities to create collectively meaningful lives (Ernstson et al. 2014).

Widening the theoretical framework of justice to facilitate examination of interlinkages between redistribution, recognition, representation and recovery offers fruitful opportunities to 
approach governance and justice as an arena of negotiations and contestations. As Harvey (2008: 23) remarks: 'The right to the city is far more than the individual liberty to access urban resources: it is a right to change ourselves by changing the city.' Approaching justice as the right to a safe living environment and access to services requires a careful analysis of inequalities and interconnectivities inherent in cities, including the institutional modes of regulating urban spaces and populations. Given the scale of vulnerabilities characteristic of contemporary cities, addressing these issues is crucial to theories of justice, and the cognate fields of governance, inequality and segregation, and the right to the city (Attoh 2011, de Vries 2016, Holston 2011, Merrifield 2014, Tonkiss 2013).

This analysis contributes to a holistic approach to justice by examining a series of linkages important for understanding the (re)production of inequalities through interconnectivities: first, by demonstrating the entanglements in the notion of justice as redistribution, recognition, representation and recovery; second, by illustrating how residents' exposure to risks relates with their access to services and how these interconnections are produced through everyday interactions between the authorities and socially differentiated residents; and third, by showing how residents seek tactics to reconfigure institutional efforts to govern their right to the city and their access to services through multifaceted, albeit differentiated, power relationships. The view of cities as conglomerates of crossclass interactions provides a more dynamic way to analyze justice in segregated cities than the conventional assumptions of insular urbanism (Cosacov and Perelman 2015). It enables an examination of how inequalities are re(produced) in everyday interactions, and how perceptions of environmental safety, societal security and life with dignity are politically charged and contested.

\section{Villahermosa: A city of contradictions and interconnections}

Villahermosa is located at the confluence of two of the biggest rivers in Mexico: the Grijalva and the Carrizal. The hydrology of these rivers has been changed many times through massive infrastructure, including a series of dams, dykes and flood-walls, as well as transformations due to oil extraction and 
filling lagoons for construction purposes (Aparicio et al. 2009). Situated on the wetlands, mostly less than ten meters above sea level, Villahermosa is subject to frequent flooding. The exceptionally serious disaster in 2007 was an outcome of an interplay of bio-physical and socio-political factors, including a tropical storm that provoked heavy rainfall in the upper basin, sedimentation of the rivers due to agricultural land-use, questionable operation of hydro-electric dams and urban planning that ignored the disparities in residents' vulnerability in the face of flooding (Nygren 2016)

To analyze the multi-dimensionality of justice issues, I selected three socio-economically differentiated sites in Villahermosa - Tabasco 2000 as an elite residential area, El Guayabal as a middle-class neighborhood and Gaviotas Sur as an informal settlement - for ethnographic analysis, based on the idea that these sites represent relevant cases for delineating the differences in risk governance and service provision in a socially fragmented city. Tabasco 2000 consists of gated communities that provide housing for high-ranking business managers, upper-level oil industry staff and political elites. Parts of Tabasco 2000 have been built in a flood-risk area by constructing floodprotection infrastructure. The middle-class neighborhood of El Guayabal is situated near the historic center, with many government offices and medium-size enterprises. Most of its residents are middleincome employees: schoolteachers, government officials and oil-industry technicians. Although temporary floods occur, the magnitude of the 2007 flood was a shock for El Guayabal residents. In the informal settlement of Gaviotas Sur, the poorest households live in corrugated iron huts alongside better-off families inhabiting one- to two-storey concrete houses. Most of the Gaviotas Sur residents subsist through manual jobs, part-time domestic work or informal trade. The area suffers yearly from flooding, and during the 2007 flood the government declared it a catastrophe area.

Instead of considering different neighborhoods as discrete worlds, I examine heterogeneous flood-governance strategies and services provided alongside each other, and how socially differentiated residents interconnect through employment, service-provision and other points of contact. Detailed analysis is required to understand how claims related to governance and justice are produced, legitimated and contested through negotiations and disputes between diverse actors 
operating in hierarchical relationships with each other.

The information presented in this study is based on in-depth interviews and participant observations between 2011 and 2106. Of the 50 interviews conducted with local residents, 13 were carried out in Tabasco 2000, 17 in el Guayabal and 20 in Gaviotas Sur. The informants were selected considering the variation in living conditions and life experience according to age, gender, social position, political power and length of residence. In the interviews, the subject of services - including water, electricity, sewage, drainage, waste-collection, education, health-care, security and recreation

- was explored, in addition to residents' experiences of disasters and views of vulnerabilities. Observing quotidian interactions in streets, stores, marketplaces and workshops helped me to understand the contextual shifts in people's views of justice and explanations of inequalities. Fieldwork required complex navigations across multiple power hierarchies; it was especially difficult to get access to the gated communities of Tabasco 2000 as residents of these privileged spaces were suspicious about the purposes of my study and reluctant to share information on (in)justice. In addition to interviews, our research team administered a survey to 300 households in the three neighborhoods to gain a wider understanding of the living conditions in different parts of the city. The questionnaire included queries on access to and quality of services, and the nature of risks and vulnerabilities characteristic of different neighborhoods.

In addition, I conducted 55 interviews on urban risk governance and service provision with federal, state and municipal-level authorities, private consultants and representatives of NGOs. I also organized various policy-dialogue workshops to facilitate debate on governance and justice between different stakeholders. These data were complemented by qualitative content analysis of policy documents, urban development plans and flood governance reports.

\section{Distributive justice: Exposure to risks and access to services}

An examination of justice in terms of (re)distribution needs to consider not only the questions of who 
lives in risk areas, and why, but also how the distribution of services and social well-being differs across a particular space. As the following analysis will show, people's exposure to risks and access to services are far more complex than usually captured through categorical classifications of haves and have-nots (Anand 2011). This is so because the injustices related to socio-spatial distribution of risks are entangled with inequalities in access to services; furthermore, instead of strict separations of formal versus informal services, it is necessary to consider interconnections between different forms of service delivery and how the covert governance involved in them insulates service provision from public scrutiny. Exposure to risks and access to services are often neglected aspects in evaluations of justice, issues this study examines through analysis of the quality of risk protection and service delivery available for different residential groups.

The 2007 disaster in Tabasco caused technical flood protection measures to be integrated into social resilience strategies which urge people to re-orient themselves away from fighting against water to living with it (CONAGUA 2011). Simultaneously, service delivery schemes have shifted toward public-private partnerships, blurring the divisions between the state, market and civil society. The socio-spatial distribution of flood risks in Villahermosa cannot be understood without considering how service provision renders some groups more vulnerable than others. A crucial issue in this respect is the living conditions of different neighborhoods, particularly with regards homeownership. In my interviews, both the authorities and residents drew sharp distinctions between those with legitimate claims of home-ownership and those without. Upper and middle-class residents were eager to emphasize their status as property owners in contrast to tenants, squatters and vagrants living in informal settlements.

The affluent communities of Tabasco 2000 were regularized by the municipality right after their construction in the 1980s; in the middle-class community of El Guayabal, 1990s' regularization increased property values and facilitated enhanced services; while, in Gaviotas Sur, residents struggle to gain governmental recognition of their tenure status and access to basic services. However, if it materializes, regularization will transform the position of many Gaviotas Sur residents from informal 
inhabitants to illegal squatters, with a risk of eviction if they are unable to provide evidence of their long-term residency. The situation is further complicated by several de facto regularizations, such as when politicians have persuaded the poor to settle to garner votes. Furthermore, after regularization residents need to pay land taxes and fees for services, which many cannot afford.

Recently, government institutes have produced detailed maps of the critical flood risk zones in Villahermosa (SEDEDSOL 2009, SEGOB 2015), followed by forceful relocations of informal residents from these areas, including parts of Gaviotas Sur. According to archival data, plans to relocate these people had existed since the 1990s; however, political sensitivity had caused the authorities to postpone these efforts. The 2007 flood provided a pretext to 'clean' the informal settlements near the center in the name of saving the city from a future disaster. Interestingly, many affluent and middle-class residences have also been built in high risk areas or on lands that otherwise violate legislation. As Ghertner (2011: 153-154) notes in the case of Delhi, if the government were to terminate all unauthorized land use, many affluent neighborhoods, commercial centers and industrial facilities would also be razed. The boundary between legal settlements and illegal encroachments, and between risky and safe living environments, is anything but clear in everyday policy and planning.

In terms of housing, Tabasco 2000 has the reputation of an elite enclave, manifested in luxurious mansions. According to our questionnaire data, $92 \%$ of the Tabasco 2000 residents have legal home-ownership while $8 \%$ of them are house-renters under an official contract (Teno 2012). In the spatially adjacent informal settlement of Gaviotas Sur, people live in rustic concrete houses and corrugated iron shacks, with precarious home-ownership. Some better-off landlords rent rooms under complex arrangements: Different categories of subtenants usually inhabit the rooms of a flood-prone, lower-level storey, while tenants live on the slightly safer, upper levels.

Concerning access to services, as Table 1 shows, instead of categorical distinctions between those with, versus without, access, I have sought to understand the social differentiation in diverse forms of service provision in Villahermosa. Residents of Tabasco 2000 accrue the benefits of public 
capital expenditure, with reliable water and electricity supplies and well-functioning drainage and sewage systems, while residents of Gaviotas Sur suffer from irregular water and electricity provision and a lack of drainage and sewerage. Education, health care and security services have been largely privatized in Tabasco 2000; in El Guayabal, people use a mixture of public and private services; while in Gaviotas Sur informal services supplement the poor services provided by the municipality.

In relation to water supply, everyone in Villahermosa buys drinking water, as piped water is not potable. Costs are, however, highly uneven, with the poorest households of Gaviotas Sur spending a much greater proportion of their income on water than the residents of Tabasco 2000. To reduce expenditure, low profile water kiosks have been established in informal settlements where residents can buy purified water at half the price of bottled spring water (Isomarkku 2012: 72). The piped water used for washing comes to Tabasco 2000 from a well, while Gaviotas Sur is supplied by the Grijalva River which contains organic compounds, heavy metals and toxins due to domestic and industrial waste water being discharged untreated into the river. Furthermore, supply is intermittent in Gaviotas Sur: at times women have to wait for hours to get enough water for washing while at others the water emerges under so much pressure that it is mixed with mud. Due to the lack of sewerage, rain and waste water combine in the muddy alleys of Gaviotas Sur, provoking serious health problems. As Perreault (2014: 240) notes, a formal right to water means little to those who lack the infrastructure to access it and who cannot prevent themselves being exposed to contaminated water. The authorities, who argue that water privatization means economic efficiency because the consumers pay the cost of the burden they impose on the system, ignore the fact that in terms of distributive justice, the price of water should be adjusted to people's ability to pay. Currently, most of the Gaviotas Sur residents connect their water pipes informally to public networks.

Correspondingly, measuring a formal electricity grid does not illuminate the energy supply in many Southern cities, where households deploy a range of tactics to gain access to heterogeneous services (Silver 2014). In Tabasco 2000, the supply is stabilized by transformers located in every street and by back-up generators situated in every house, while in Gaviotas Sur, electricity is obtained 
through unauthorized connections and off-grid generators. Furthermore, a connection to an official grid does not ensure a reliable supply, as politically instituted power cuts at peak times frequently affect poor neighborhoods.

A detailed analysis of service provisions also demonstrates how informal services are not based simply on improvised acts of everyday resistance, but on relational patterns of governance and inequality. Although the authorities denounce informal water and electricity connections as illegal, in everyday politics they often tacitly support them. Considering the hundreds of illegal electricity wires, called diablitos (small devils), hanging from the lines in Gaviotas Sur, not to speak of the collective efforts required for their maintenance, these networks are far from clandestine (Boelens 2009, Meehan 2013). The issue is more that authorities are unwilling to dismantle these connections because denying people access to water or electricity is politically risky. Thus, the poor are left at the mercy of unreliable options at the edges of informality; as Tony, working in a metal workshop in Gaviotas Sur noted: 'Although we're not located far from the center, in terms of services we are.'

In relation to waste management, a semi-private company is responsible for collecting garbage in Villahermosa. In Tabasco 2000, there are cans with separate containers for different kind of trash, while in Gaviotas Sur, people have to be alert to the garbage truck's passing, as they cannot leave trash bags on the street because of the wandering dogs. Many women noted that the blame for the neighborhood's garbage problem cannot be placed just on the residents; rather, the waste removal company should regularize its collection times. Furthermore, the city provides free street sweeping services in Tabasco 2000; in El Guayabal people pay for informal street sweepers; while in Gaviotas Sur the residents themselves sweep the streets in front of their houses every morning. In addition, upper-class neighborhoods have the means to oppose the siting of landfills and polluting industries near their homes, while poor settlements often become an easy target for such facilities.

In terms of employment, many residents of Gaviotas Sur carry out low paid jobs and provide various kinds of informal services to affluent residents of Tabasco 2000. My interviews in Gaviotas Sur produced a long list of occupations, including masons, carpenters, blacksmiths, painters, 
mechanists, shoe-repairers, tailors, pastry-makers, sweet vendors, shoe-cleaners, chicken-vendors, rickshaw-drivers, advertisement criers and chambermaids. Others work as informal watchmen, maids or gardeners for upper-class residents, with limited labor rights. As Candelario, a street vendor at the popular market Pino Suarez, noted:

We poor are those who develop the city. We work as waitresses, plumbers, maids and street vendors. But, in a discriminatory way, they treat us badly because we're the symptoms of poverty. Wealth gives you the right to live. (April 13, 2014)

The informal workers' access to elite neighborhoods is strictly controlled; they are allowed to enter as invisible laborers, subserviently washing affluent residents' laundry, mowing their lawns, cooking their food and taking care of their children. Still, their role was rarely recognized in interviews with affluent residents. What emerged as critical was that the masters and mistresses knew the hireling, as personal, although strictly coded, relationships help to reduce the hosts' fear of workers as dishonest. Interactions are based on paternalist rules, according to which laborers should obey class-based boundaries, such as not entering the reception hall, eating separately and being humble, as Héctor, a politician from Tabasco 2000 commented:

Many households have domestic workers from Gaviotas Sur. The watchman working for us first behaved as if he were living in a rancho, greeting people loudly...But we taught him how to behave and now he acts much better. (Aug. 8, 2011)

Concerning security, while affluent residents consider their gated communities safe, many regard the middle-class-inhabited center as an important sphere of sociality, visiting the cafes for their historical atmosphere, and meeting with politicians at the Governor's Palace. Simultaneously, affluent residents avoid the overwhelming spaces of Gaviotas Sur, where the 'alleys split like a broken plate' and 'pochimóviles (rickshaws) circulate in a chaotic way' as René from Tabasco 2000 complained. Gaviotas Sur residents, however, feel at home in the crowded markets and bustling streets, reconfiguring the conventional categories of public and private by furnishing the streets in front of their houses with rocking chairs and dining tables, and establishing workshops in the alleyways. 
Correspondingly, while affluent residents prefer the private greenspaces of their gated compounds for their cocktail parties, for Gaviotas Sur residents, the few greenspaces in their neighborhood are a source of fear because of the risk of assault. For security reasons, parents prefer their children to play in a busy street rather than in a secluded park.

In the interviews and survey responses, residents from all parts of the city raised insecurity as a crucial issue concerning justice and social well-being, although their ways of dealing with it are different. Residents of Tabasco 2000 seek to exclude the dangers beyond their control with walls, guarded entrance points, private security forces and surveillance cameras, while public security officials are reluctant to patrol in Gaviotas Sur due to its reputation as a hotbed of crime. However, understanding the causes of insecurity requires a shift from identifying violations as individual acts toward analysis of the structural factors beyond them. As Rodríguez et al. (2014) note about Santiago de Chile, affluent and middle-class residents are concerned about assaults, house burglaries and car thefts, categorizing the poor as delinquent, while informal residents link violence to social exclusion from legitimate means of making a living and to organized crime and drug trafficking. In Latin America, a region with the highest rates of urban violence in the world (Muggah 2014: 351), insecurity is entangled with the state's inability or unwillingness to provide basic welfare in informal settlements. Under such conditions, trafficking groups and gangs take on part of the state's tasks of governing, simultaneously enforcing and violating security (Caldeira 2015). Given their reputation for corruption, clientelism and cruelty, people in Gaviotas Sur do not believe in getting protection from the police, as Tania, living in one of the poorest sectors of Gaviotas Sur, complained:

When there's a robbery, people report to the police, but they don't care... Sometimes the police themselves are involved. We don't trust even in our own shadows any more. (Feb. 2, 2011)

As a result of the lack of confidence in the authorities' defending their civic rights, Gaviotas Sur residents use diverse informal tactics to take care of their security: constantly observing who talks to whom, who is visiting whose house and who is doing business with whom. If not at home, they ask 
a relative to keep an eye on their belongings. These forms of self-policing and collective vigilantism, together with privatization of security services in the affluent neighborhoods, reinforce the neoliberal call for citizens to shoulder responsibility for taking care of their own lives while strengthening the punitive forms of urban governance, meaning that those at the social edge face growing violence and marginalization. Such forms of self-policing further fragment urban spaces by reducing contacts with unknown 'others' (Müller 2016: 141-142). Another tactic for managing insecurity is dispute avoidance: 'I don't disturb anybody'; 'I don't meddle in anybody's life', were typical comments when residents mentioned security. People talked about violence as something that had no face, because exposing the guilty presented a risk. The burden of self-help - including not reporting violent acts to the authorities but, rather, seeking protection through clientelistic relations with political leaders particularly affects women, as mothers take care of domestic comfort and the well-being of children.

Overall, the residents' socially differentiated exposure to risks and access to services, and the institutional politics that produce them, provide privileges for the elite while the poor have to battle with the regulations to secure the minimum of (informal) amenities. Nevertheless, assumptions of categorical segregation fall short of capturing the uneven distribution of benefits and burdens in socially fragmented cities. As I will show in the following section, cultural frames of (mis)recognition involved in everyday interactions between the authorities and different residential groups, and hierarchical encounters across class lines based on strict codes and tactics of symbolic ignorance, tend to maintain social distinctions.

\section{Frames of recognition: Governing minds}

In everyday politics, the uneven distribution of benefits and burdens is often justified by discursive representations that valorize 'certain relationships between people in particular places' (Lefebvre 1991: 32), thereby legitimating particular groups' entitlement to the city while symbolically marginalizing others (Guano 2004: 70-71). In this section, I show how differentiated exposure to 
risks and access to services is constituted through cultural frames of (mis)recognition, and how essentialist narratives operate in the (re)production of injustices.

Institutional discourses on urban planning and environmental risk management have considerable influence on the public images of different neighborhoods in Villahermosa. During my interviews, government officials made normative comments on what the city should look like and how the required socio-spatial order should be achieved. They often attached reified cultural characteristics to different neighborhoods that served to legitimize segmented services. Affluent neighborhoods were portrayed as sites of ultra-modernity and social distinction, while informal settlements were presented as spaces of unruliness and disorder. Unsanitary conditions in informal settlements were considered to stem from the residents' irresponsible lifestyles, with scant recognition given to governmental failure to provide basic amenities in these sites. According to the authorities, any investment in services in informal neighborhoods would signal formalizing squatter settlements.

Recently, the discourses of societal security have merged with those of environmental safety, producing new ways of restricting informal settlers' access to urban space. Characteristic of such discourses is the emphasis that informal settlers need to become aware of flood risks and develop new ways to live with water. In 2009, when thousands of informal settlers were displaced from the center, authorities labeled these social-cleansing operations as tools for environmental improvement. The arguments that people who lived in risk areas had deliberately chosen to settle there ignored the political-economic pressures that had made the settlement inevitable. As an official of National Water Commission (CONAGUA) argued in El Heraldo on May 5, 2011:

People have started again to cobble together shacks on the shores of the Grijalva River, knowing that they are in a very dangerous zone...It's a pity that these citizens don't understand that the removal was for their own security and...that these areas are not apt for settlement, and thus have no services; and, into the bargain, all their debris contaminates the river-beds.

These kinds of representations simplify a complex hydro-social question into an issue of unruly settlers erecting huts in a risk zone. There is scant recognition that the lack of political will to apply 
risk prevention strategies in informal settlements creates a vicious cycle of poor livelihood options, increasing vulnerability and environmental degradation. Furthermore, after the informal settlers' forced removal from the center, local newspapers announced that the government has plans to gentrify the neighborhoods through massive capital investment (Presente, May 13, 2013), clearly demonstrating that the definition of risk zones is negotiable, depending on the type of inhabitants.

The essentialist discourses generated by the authorities influence how residents themselves perceive the city's different living spheres; interviewed residents often invoked categorical views of other social groups to legitimate their own right to the city. Thus people were not competing only over material benefits, but also over the moral recognition of appropriate citizenship. Julio, an influential businessman, portrayed affluent neighborhoods as spaces of excellent standards in contrast to middle-class colonías and impoverished asentamientos:

A residential zone (zona residencial) is an exclusive area. You note the status these people have. They don't permit mechanical workshops, beauty-shops or bars in these areas because these residents have a right to relax after a demanding workday. A neighborhood (colonía) is where middle-class people construct their homes. They have documents for their properties and there are public services. A settlement (asentamiento) is where people go and occupy the land. There are ambulant traders selling tamales, fish, fruit and furniture in the streets...and neighbors meddle in whatever matter they choose. (Oct. 18, 2011)

Many upper- and middle-class residents also reiterated the institutional representations of slums as dangerous spaces, establishing delinquency as an inherent characteristic of them. As Caldeira (2008) notes, a disproportionate fear of crime relative to its occurrence is a phenomenon characteristic of segregated societies. Such discourses justify social hierarchies and blame others for unpleasant predicaments, as the comment by César, a businessman from Tabasco 2000, reveals:

In Gaviotas Sur, there is much insecurity and much noise. A water truck passing, shoe-cleaners shouting, voceros [criers] blaring with loudspeakers. Here you aren't woken up at eight o'clock in the morning by a gas truck rumbling by. Here there are no pregoneros; they are those hawkers in Gaviotas Sur crying at every corner: 'Vaaa!' [Water!] (Aug. 8, 2011)

During my interviews, middle-class residents were especially eager to voice complaints about 
informal settlers' throwing garbage in the center, considering this waste as a sign that the authorities were not maintaining social order. Such claims illustrate how people's relation to waste serves as an indication of their place within the social structure (Sletto and Nygren 2015, Whitson 2011). While normative comments were made on waste produced by the poor, simultaneously, scant attention was paid to the huge difference in the amount of waste generated by different neighborhoods. Nora's comment on the (in)appropriate place of garbage has clear links to a middle-class view of distinction:

During the rain, suddenly garbage appears at the entrance of our neighborhood. It comes from the marketplace, not from our community. It's so awful to see this garbage, belonging to nobody, or to the poor...Here in el Guayabal we have good services; they accord with our status. In Tabasco 2000, they are excellent; in Gaviotas Sur, 'God forbid!' There is a phrase: 'Tell me where you live, and I will tell you who you are.' The socio-economic status, the culture is different. (Aug. 19, 2011)

Correspondingly, there were heated debates on the place of ambulant traders, with middle-class residents claiming that the street vendors were invading their living-sphere and disturbing their lifequality. While cafeterias are allowed to expand their terraces on the center's pedestrian streets, ambulant traders selling popsicles, cuddly toys and CDs are considered illegitimate intruders. The authorities support the middle-class residents' moral contestation of street vendors' presence in the center, terming their activities subterranean economies and frequently ordering their removal based on the argument that peddlers and beggars disturb the center's otherwise cultivated atmosphere. Commenting on street vendors who were protesting against the authorities' tightened hygiene rules, Simón, a medium-sized retailer, presented the vendors as intrusive others, a tactic commonly used by the middle class (Guano 2004):

Those who are protesting are ambulant traders; they're not established businessmen. They don't even pay the VAT [value added tax]...They throw a lot of garbage and they sell pirated things... The authorities want to relocate them. They don't forbid them to do business; they are just asking that they don't do it in the center. (Aug. 7, 2011)

These boundary-makings express the spatial distance and temporal liminality imposed on ambulant traders as subterranean and transient. Many middle-class residents portrayed street vendors as 
misusers of space, who escape their allotted space to penetrate that of the middle-classes, trespassing on the way of life the latter consider fundamental to their identity (Bénit-Gbaffou 2016, Guano 2004, Whitson 2011). Similar categorizations emerge in the middle-class residents' arguments that informal settlers are not the type of people they would like to settle in their neighborhood. According to this view, middle-class residents are allowed to settle in low-income neighborhoods, but not vice versa.

In my interviews and daily conversations, Gaviotas Sur residents sometimes repeated the dominant discourses of informal settlements as places of social ills and themselves as culpable for flood damages for not obeying the rules. They also told me that, when applying for work, they often hide their home location because the public image of Gaviotas Sur is so repellent that if an employer discovers their address, they may not get the job. This indicates how symbolic domination is sometimes exercised with the poor's complicity (Auyero and Swistun 2009: 93), and how such labels constrain people's opportunities to imagine alternative pathways, as Josefina, a street vendor from Gaviotas Sur, explained:

There is like a wall between us and the government. They don't understand our needs. With regards the flooding, the conclusion that people drew was that it happened because they didn't open the spillways of the dam reservoirs in time. Heavy rains came and the reservoirs were full of water. But, well, we aren't allowed to give our opinions. (Aug. 2, 2011)

Recently, neoliberal discourses of self-governance have gained increased institutional support in Mexico, as elsewhere in Latin America. Instead of promoting improved public services, these careof-the-self discourses encourage residents to take responsibility for their own well-being. During my interviews, the authorities emphasized the need for informal settlers to eradicate paternalistic suppositions that the government should help in everything, and develop capacities for selfgovernance. Such views displace the responsibility for risk prevention and service provision onto the shoulders of citizens, leaving people to seek individual solutions to socially produced problems (Rajak 2011: 13). As an official of the Ministry of Environment and Natural Resources (SEMARNAT) stated: 
People throw waste wherever...Participation and civic volunteering are highly important, as well as awareness-raising among residents living in the high risk zones. (Feb. 15, 2011)

These claims for self-achievement are highly appealing to upper-class residents of Tabasco 2000, who often constitute their social position by pointing out that since they pay huge taxes and contribute significantly to the national economy, they deserve better services and more efficient protection from flood risks than the slum-dwellers, who, according to them, lack initiative. Gaviotas Sur residents contest the affluent residents' accusations of lack of initiative by emphasizing how they have constructed their neighborhoods through their own efforts due to governmental inattention. They also make painful comparisons between the deficiency of services available in their own neighborhood and those provided for the elite, which are of a quality beyond the poor's aspirations. As my analysis in this section has shown, dominant frames of (mis)recognition reinforce the existing socio-spatial order, while legitimating the ways symbolic boundaries are drawn within the socially segmented spaces of the city. As the next section will demonstrate, this legitimization covers also the arenas of political representation available for different resident groups.

\section{Political representation and representative justice}

This section examines justice in terms of representation, exploring how institutional politics of relation-making shape the opportunities different residential groups have to get involved in decisionmaking. Political representation is understood here as an arena of collaboration, competition and contestation between different governmental, private and civil society actors, including local residents, with their often controversial agendas. In such arenas, some actors have more opportunities to make themselves heard than others.

In my interviews and informal conversations, residents from the various sectors explained how they try to navigate the labyrinth of bureaucracy: filing petitions, appealing for services and 
lodging complaints about mistreatment through formal and informal channels. Affluent residents emphasized that they pressure authorities by virtue of their personal networks - calling directly to the governor or the mayor, and arranging appointments with this or that federal-level politician - while informal settlers explained how they strive to persuade community leaders and lower-level officials to forward reports of their plights to upper-level authorities. In exchange for these favors, petitioners are expected to show loyalty toward particular candidates in the elections. As the following comments demonstrate - the first from Roy (Tabasco 2000) and the second from Tomás (Gaviotas Sur) officials are considered a 'source to be milked' under the system of political clientelism:

We have mechanisms for making demands of the authorities. If I pay taxes, how can it be that they don't serve me? They have to fulfill my rights. (Aug. 11, 2011)

The power works in a way that as I give you resources, you support my politics... Nobody is interested in the poor...only when the elections are coming up; then we play an important role because we have many votes. (Oct. 16, 2011)

Regardless of social status or political affiliation, residents in all neighborhoods showed considerable mistrust of public institutions, with people everywhere claiming that the government had abandoned them and that they are not properly taken into account. Middle-class residents of El Guayabal were particularly irritated by the government's financing the façade-painting of historical buildings instead of programs that would really improve their lives, such as enhanced public security. Informal residents of Gaviotas Sur told me how authorities repeatedly put them through the ringer. When they claim basic amenities, officials set them strict schedules of house-tax records; when attempting to file petitions for flood-damage compensation, officials initially postpone their appointments and thereafter claim that another institution is responsible.

Interestingly, while the presence of public officials is meager in informal settlements, there is a strong drive towards policing such places. The experience of governance among the residents of Gaviotas Sur is thus a mixture of absence and intrusion. Officials present patronizing views of how 
informal residents need to be educated so that they can be integrated into formal city life, meanwhile paying scant attention to the political-economic forces that shape the residents' vulnerability. By maintaining informal residents at the legal margin, authorities sustain their social fragility, and in this way dissipate their collective demands for justice (Bogaert 2011: 714-715). These procedures essentialize informal settlements as spaces to be governed separately, thereby obfuscating the links through which different sites of the city are hierarchically interconnected.

Such mechanisms support the interests of the elite, who consider that social inequalities stem from divergent capacities for progress at the level of individuals, basing their own demands for special treatment on their socio-economic achievements. Correspondingly, middle-class residents present themselves as honest and industrious citizens in their claims for improved services. Within the structures of differentiated citizenship, where the authorities grant favors to particular groups, civic rights turn into privileges to be gained through paternalistic networks (Hilgers 2012, Holston 2011). Informal residents challenge such modes of political representation, claiming that all citizens have the right to basic amenities and protection from hazards. They also point out that instead of the government's outsourcing its tasks to private and civil society actors, and in this way taking institutional decisions out of sight of public scrutiny, it is the responsibility of the state to invest in service infrastructure and risk management.

In these circumstances, the institutional rhetoric of uniform opportunities for everyone contradicts the uneven incorporation of the poor into neoliberal forms of political representation. The government's reaction to initiatives to overcome representational hierarchies through more horizontal networks is unresponsive, although the authorities tolerate certain practices of informal service provision as a means to reduce their own responsibilities. Illegal electricity and water connections are acceptable irregularities, as they transfer the burden of infrastructure maintenance to individual and community initiatives (Meehan 2103).

Although counter-actions against prevailing policies and forms of political representation emerge now and then, the government is quick to repress mobilizations either by force or by political 
persuasion. This became clear in the contestations that arose against governmental efforts to relocate street vendors from the center. Middle-class residents and formally established businessmen argued for strict standards of hygiene and social order, blaming street vendors for tax evasion and political agitation. Street vendors themselves made it clear that their struggle was not just a battle over the principles of hygiene; it was also a struggle for recognition of informal economies as one of the few ways for the poor to sustain themselves. In 2011 and 2012 street vendors protested by blocking streets and asking to negotiate with the governor; however, these efforts did not lead to any results. Little by little the passion of the resistance faded due to the lack of institutional response.

Such conditions make Villahermosa a case of dispersed justice claims and fragile contestations. As institutional structures frequently constrain political mobilizations, people seek to overcome injustices through everyday resistance. Some residents of Gaviotas Sur have informally upgraded their corrugated iron huts to cement houses, imitating government-defined construction standards although without juridical anchorage. They base their actions on the notion that while informal residents in corrugated iron huts have frequently been removed by force, residents in cement houses have rarely endured similar treatment, 'irrespective of the illegality being the same' (Nielsen 2011: 349). The residents also fill their plots with sand and waste to demonstrate to the authorities that they are living within the flood risk limits. Through such tactics they seek to legalize their right to residency and thereby right to the city, as Miriam from Gaviotas Sur explained:

My house is of...cement, and it already has a banqueta [sidewalk] in front of the house. It thus has a different value than a house of wood or corrugated iron. (Feb. 10, 2011)

Such forms of everyday resistance are not merely desperate coping strategies; they also critically compromise the officials' authority to control the city (Anand 2011, Boelens et al. 2016). Through tactics of reconfiguration, informal residents confront the forms of urban planning that affect them profoundly but into which they are unevenly incorporated. At the same time, they participate in all kinds of government-sponsored events linked to neighborhood development, even if they do not 
consider them relevant. These tactics are more about gaining a tiny foothold in political representation as legitimate stakeholders, and not merely as onlookers, in circumstances where there is a deep connection between the right to be represented and the right to belong to the city (Attoah 2011).

During my interviews, residents of Gaviotas Sur often presented their right to the city as something that they deserve on the basis of building their homes and daily lives within it (Holston 2011, Sletto and Nygren 2015). Through such reflections, people have become aware that if they do not look out for their rights, nobody else is going to do it. At the same time, they recognize that an awareness of rights does not yet guarantee political representation, nor does it ensure getting justice. As long as the claims for the right to the city and for representative justice do not restructure prevailing forms of governance, dissent remains institutionally contained. The mechanisms of paternalistic governance mixed with neoliberal forms of public-private partnerships and demands for selfresponsibilization (Guarneros-Meza 2009, Müller 2016: 147-149) encourage socially differentiated procedures of political representation that favor the interests of elite while discouraging social mobilization and making acts of informal resistance politically fragile.

\section{Recovering from disasters and coping with vulnerabilities}

With regards to risks and vulnerabilities, there is an urgent need to expand the field of justice in the direction of recovery, an issue to which most justice scholars have paid scant attention. In this section, I analyze the recovery aspects of justice in connection with other dimensions of justice, showing a web of interlinkages in people's ways to recuperate from disasters and cope with everyday vulnerabilities. Although different residential groups in Villahermosa share the risk of flooding, their possibilities of rebounding from catastrophic floods are linked to socio-economic status and social conditions of living. Careful consideration of how inequality affects disaster victimization and recovery can provide important insights into the role power plays in disaster and its aftermath.

Government officials and private consultants present flood hazards as calculable risks in their 
policy documents and risk assessment reports, aiming to produce a view of manageable conditions. For local residents, however, floods are political products and technical unknowns whose effects are difficult to predict. Informal residents' experiences of loss due to catastrophic flooding powerfully contradict government officials' narratives of how to manage risks through careful calculation. For informal residents, risk management is a contingent effort to cope with emergencies as they occur. The 2007 flood took many of them by surprise, leading to abysmal material damage and deterioration in psychological wellbeing as thousands of families lost their homes, jobs and belongings.

Policy documents also emphasize flood risk management as a matter of cultural adaptation, promoting the traditional culture of water as a valuable asset for human adjustment (CONAGUA 2011). However, instead of flimsy requests for the residents to readopt traditional ways of living with water, what is needed for a detailed understanding of justice as recovery is a thorough examination of what living at risk is about and how people's exposure to risks and vulnerabilities is socially differentiated and politically mediated. In my interviews, all the residential groups emphasized their anxiety about living in an environment in which capricious rivers overflow without notice. However, whereas the government invests in the construction of dykes, water channels and modern pumping stations for flood protection in affluent and middle-class neighborhoods, informal residents are either forcefully relocated from risk areas or asked to develop their own modes self-protection and social resilience capabilities.

In my interviews, residents of Gaviotas Sur often described themselves as living at the edge, straddling the borders of high risk and intense vulnerability. Unpredictable rivers have an overwhelming presence in their lives, as the metaphors commonly used clearly demonstrate: 'the river is always there'; 'the river has a memory'; 'the river searches her course'; 'the river takes revenge'; 'the river rushes in like a snake attacking'; and 'the river does not respect anybody'. Based on their intimate knowledge of what it is to live in volatile circumstances, it is difficult to argue that these people inhabit risk areas simply because of a low degree of awareness (Lahiri-Dutt and Samanta 2013: 29); it is more a question of a lack of alternatives, as many Gaviotas Sur residents noted with a 
sigh during interviews: 'This is my home and this is my neighborhood; and in any case, where else could I go?'

Overall, residents' reflections on the capabilities needed for recovery showed important linkages to class and gender. The lower-class women in particular told me dozens of 'reboundingfrom-disaster' narratives that help them to deal with the plight of living in a zone of unpredictability and to overcome the traumas thereby inflicted. As Tina from Gaviotas Sur explained when talking about the 2007 flood, women often take the lead in efforts to recover when turmoil threatens the family's well-being, while men play a role in spurring the family back to normal life:

When we returned it was a chaos...mud up to our knees. Looking around I began to cry. Losing everything in a few hours; how do you start over? My husband asked me, 'Why are you crying; we need to begin to work and move on.' Thus we cleaned the house. With the reminder that we need to work and look forward, I pulled myself together...My husband sells antojitos [snack foods] by tricycle; I cook them for him. (Aug. 12, 2011)

While this type of narrative illustrates people's extraordinary capacities for self-reliance and resolve, the constraints informal residents encounter in recovery are difficult to understand without taking into account the material conditions of marginalization and symbolic politics of submission which aggravate the impact of disaster on their everyday lives. Although subjective, such narratives of recovery are not idiosyncratic (Auyero and Swistun 2009: 131); they reflect the informal residents' collectively framed perceptions of struggles to recover from grievances, shaped by their position as materially and symbolically deprived people in comparison to other social groups.

In addition to the capacity to recover from disasters, informal residents also need the ability to endure many kinds of daily uncertainties, including economic deprivation, unemployment, health risks, violence and lack of societal security. While some of the informal residents focus on daily routines as a strategy to overcome difficult moments, others oppose the role of self-responsible citizens they are asked to adopt, arguing that is the responsibility of the government to facilitate decent living conditions for all citizens. However, being capable of questioning the inequality does not yet 
mean that such reflections will lead to mobilization, nor does it guarantee that possible acts of contestation would result in significant changes in governance structures.

To encompass a more nuanced view of justice as recovery, it is important also to explore the routes taken by different residents to formulating new ways of living together in a socially segmented city. Characteristic of recent urban justice claims is the search for strategies to create more inclusive cities by reformulating environmental justice and social well-being so that residents are able to recognize themselves as acting subjects, instead of letting themselves be constituted by others. During my interviews, residents of gated communities often lamented that they did not know even their nearest neighbors, and that the high rates of crime obliged them to practice ephemeral ways of being social. Middle-class residents were more disposed to proposals for increased interaction between different social groups, as long as they were implemented in ways that maintained certain distinction between the 'exemplary' middle classes and 'inferior' lower classes. Informal residents emphasized how well they knew every corner of their part of the city, meanwhile comparing their experiences of deprivation and disregard with life in other sectors. Both affluent and informal residents thus felt a certain half-fledged belonging or 'throwntogetherness' (Massey 2004: 13) in conditions where hierarchical forms of governing and unyielding norms of interacting had frozen their relationships with other social groups.

Relatively little is known, in fact, about how people manage social tensions in segregated cities. In Villahermosa, many lower-class women emphasized their right to work and to move around the city, not just by occupying it but by living the space. At the same time, they criticized governmental agendas to mitigate violence and social fragility through programs of community policing and self-governance, pointing out that such agendas neglect the harsh realities they inhabit. Projects focusing on residents' consciousness-raising conceptualize recuperation as an individual coping strategy, rather than a project of societal change that would transform structural conditions affecting deprivation, insecurity and segregation (Muggah 2014, Müller 2016). This should include proposals for diversified social housing, mixed neighborhoods and more inclusive forms of urban 
planning to create spaces that have people's aspirations built into the design and that respect diverse ways of being social.

\section{Conclusion}

This essay has analyzed justice as a multi-dimensional and contested frame by examining inequalities and interconnections related to flood governance and service disposal in the city of Villahermosa, Mexico. In addition to analyzing the socio-spatial (re)distribution of benefits and burdens between different residential groups, the study explored the cultural recognition of the causes and consequences of flood risks, the channels of political representation available for different residential groups and the ways whereby residents strive to recover from disasters and cope with vulnerabilities. Such a multi-dimensional approach to justice, and to cognate fields of right to the city and inequality and segregation, enables an integrated understanding of what the socio-spatiality of governance and justice means in people's everyday lives in socially segregated cities.

An analysis of relationality is a key to comprehending the socio-spatial production of inequalities through the neoliberal governance in socially segmented cities; nevertheless, relations between different social groups in their claims for protection from risks and access to services is a scantily explored issue. My analysis has demonstrated how institutional forms of governing, together with hierarchical norms of interaction, produce multifaceted inequalities in residents' exposure to risks and access to services and in this way legitimate the prevailing socio-spatial order. The authorities' and upper- and middle-class residents' compartmentalized views of urban governance and planning reinforce policies that enable many kinds of privileges to better-off social groups.

Instead of considering segregated cities as composed of insulated worlds, my analysis has shown how inequalities and injustices are (re)produced through hierarchical interactions and power relations between authorities and different social groups. Hence, despite cross-class interactions, there is huge variation in different groups' explanations of the causes and consequences of people's socially 
differentiated exposure to risks and access to services. Hierarchical modes of governing, essentialist frames of recognition and clientelistic arenas of political representation reinforce segmented risk management and service delivery, while symbolic norms of interaction safeguard social position in relation to antagonistic others (Cosacov and Perelman 2015, Müller 2016: 149).

Nevertheless, in everyday practice institutional procedures of (mis)recognition and (mis)representation are reconfigured in myriad ways. The tactics that differently positioned residents use to accommodate, reconfigure and contest institutional endeavors to place them in categorical positions link with their socially differentiated ways of constructing urban space and claiming rights to the city. De jure and de facto rules are deeply intertwined, while government authorities, unable or unwilling to provide services for all citizens, tacitly support informal service provision to maintain social order and guarantee their institutional legitimacy. Such forms of governing reinforce the dependence on informalities of certain population groups, meanwhile making them responsible for self-improving their living conditions and capabilities for recovery.

The implications of this analysis extend far beyond the context of Villahermosa, having significant resonance with many socially segregated cities in the global South. The results of this study suggest the need for more serious attention to urban governance, risk management and service delivery as socially differentiating and politically charged processes with complicated interactions between institutional authorities and different groups of residents. These issues have crucial significance both for analytical understanding of governance and justice and for the creation of more inclusive and socially sensitive strategies for urban policy and planning. 


\section{References}

Anand, N., 2011. Pressure: The politecnics of water supply in Mumbai. Cultural Anthropology 26 (4), 542-564.

Aparicio, J., Martínez-Austria, P.F., Güiton, A., Ramírez, A.I., 2009. Floods in Tabasco, Mexico: a diagnosis and proposal for courses of action. Journal of Flood Risk Management 2 (2), 132-138.

Attoh, K., 2011. What kind of a right is the right to the city? Progress in Human Geography 35 (5), $669-685$.

Auyero, J., Swistun, D.A. 2009. Flammable: Environmental suffering in an Argentine Shantytown. Oxford University Press, Oxford.

Benit-Gbaffou, C., 2016. Do street traders have the 'right to the city'? The politics of street trader organisations in the inner city Johannesburg, post-Operation Clean Sweep. Third World Quarterly 37 (6), 1102-1129.

Boelens, R., 2009. The politics of disciplining water rights. Development and Change 40 (2), 307331.

Boelens, R, Hoogesteger, J., Swyngedouw, E., Vos, J., Wester, P., 2016. Hydrosocial territories: a political ecology perspective. Water International 41 (1), 1-14.

Bogaert, K., 2011. The problem of slums: shifting methods of neoliberal urban government in Morocco. Development and Change 42 (3), 709-731.

Bullard, R.D., Wright, B., 2009. Race, Place, and Environmental Justice after Hurricane Katrina. Westview Press, Boulder, CO.

Caldeira, T.P.R., 2008. From modernism to neoliberalism in São Paulo: reconfiguring the city and its citizens. In: A. Huyssen (Ed.) Other Cities, Other Worlds: Urban Imaginaries in a Globalizing Age. Duke University Press, Durham, NC, pp. 51-77.

Caldeira, T.P.R., 2015. Social movements, cultural production, and protests: São Paulo's shifting political landscape. Current Anthropology 56 (S11), 126-136. 
Centner, R., 2012. Microcitizenships: fractious forms of urban belonging after Argentine neoliberalism. International Journal of Urban and Regional Research 36 (2), 336-362.

CEPAL (Comisión Económica para América Latina), 2008. Tabasco: características e impacto socioeconómico de las inundaciones provocadas a finales de octubre y a comienzos de noviembre de 2007 por el frente frío número 4. CEPAL, México, D.F: México, D.F.

CONAGUA (Comisión Nacional de Agua), 2011. Cultura del agua. http://www.conagua.gob.mx/Contenido.aspx?n1=6\&n2=200\&n3=200, accessed July 23, 2011.

Cosacov, N., Perelman, M.D., 2015. Struggles over the use of public space: exploring moralities and narratives of inequality. Cartoneros and vecinos in Buenos Aires. Journal of Latin American Studies 47 (3), 521-542.

de Vries, P., 2016. The inconsistent city, participatory planning, and the part of no part in Recife, Brazil. Antipode 48 (3), 790-808.

Ernstson, H., Lawhon, M., Duminy, J., 2014. Conceptual vectors of African urbanism: 'engaged theory-making' and 'platforms of engagement'. Regional Studies 48 (9), 1563-1577.

Fraser, N., 2008. Abnormal justice. Critical Inquiry 34 (3), 393-422.

Fraser, N., 2009. Scales of Justice: Reimagining Political Space in a Globalizing World. Columbia University Press, New York.

Ghertner, D.A., 2012. Nuisance talk and the propriety of property: middle class discourse of a slumfree Delhi. Antipode 44 (49), 1161-1187.

Ghertner, D.A., 2011. Green evictions: environmental discourses of a 'slum-free' Delhi. In: Peet, R., Robbins, P., Watts, M.J. (Eds.) Global Political Ecology. Routledge, London, pp. 145-165.

Guano, E., 2004. Of modernity: transnational imagination and local hegemonies in neoliberal Buenos Aires. Cultural Anthropology 17 (2), 181-209.

Guarneros-Meza, V., 2009. Mexican urban governance: how old and new institutions coexist and interact. International Journal of Urban and Regional Research 33 (2), 463-482. 
Harvey, D., 2008. The right to the city. New Left Review 53 (Sept.-Oct.), 23-40.

Hilgers, T., ed. 2012. Clientelism in everyday Latin American politics. Basingstoke: Palgrave.

Holston, J., 2011. Contesting privilege with right: The transformation of differentiated citizenship in Brazil. Citizenship Studies 15 (3-4), 335-352.

Isomarkku, E., 2012. Patterns of Quality: Residents' Access to Urban Services in the City of Villahermosa. Unpubl. Master Thesis, Development Studies, University of Helsinki, Finland.

Lahiri-Dutt, K., Samanta, G., 2013. Dancing with the river: People and Life on the Chars of South Asia. Yale University Press, New Haven.

Lefebvre, H., 1991. The Production of Space. Blackwell, Oxford.

Massey, D., 2004. For Space. Routledge, London.

Meehan, K., 2013. Disciplining de facto development: water theft and hydrosocial order in Tijuana. Environment and Planning D: Society and Space 31 (2), 319-336.

Merrifield, A., 2014. The New Urban Question. Pluto Press, London.

Mohai, P., Pellow, D., Timmons Roberts, J. 2009. Environmental justice. Annual Review of Environment and Resources 34, 405-430.

Muggah, R., 2014. Deconstructing the fragile city: exploring insecurity, violence and resilience. Environment and Urbanization 26 (2), 345-358.

Müller, M-M., 2016. The punitive city: Privatized policing and protection in neoliberal Mexico. Verso, London.

Nygren, A., 2016. Socially differentiated urban flood governance in Mexico: ambiguous negotiations and fragmented contestations. Journal of Latin American Studies 48 (2), 335-365.

Nygren, A., 2014. Eco-imperialism and environmental justice. In: Lockie, S, Sonnenfeld, D.A., Fisher, D.R (Eds.) Routledge International Handbook of Social and Environmental Change. Routledge, London, pp. 58-69.

Perreault, T., 2014. What kind of governance for what kind of equity? Towards a theorization of justice in water governance. Water International 39 (2), 233-245. 
Rajak, D., 2011. In Good Company: An Anatomy of Corporate Social Responsibility. Stanford University Press, Stanford, CA.

Rinne P., Nygren, A., 2016. From resistance to resilience: media discourses on urban flood governance in Mexico. Journal of Environmental Policy and Planning 18 (1), 4-26.

Rodríguez, A., Rodríguez, P., Saborido, M., Segovia, O., Mires, L., 2014. Visible and invisible violence and inequality in neoliberal Santiago. Environment and Urbanization 26 (2), 359-372.

Silver, J., 2014. Incremental infrastructures. Urban Geography 35 (6), 788-804.

Schlosberg, D., 2013. Theorising environmental justice: the expanding sphere of a discourse. Environmental Politics 22 (1), 37-55.

SEDESOL (Secretaría de Desarrollo Social), 2009. Altas de Riesgos de Municipio de Centro. SEDESOL, Villahermosa.

Sletto, B., Nygren, A., 2015. Unsettling neoliberal rationalities: engaged ethnography and the meanings of responsibility in the Dominican Republic and Mexico. International Journal of Urban and Regional Research 39 (5), 965-983.

SOTOP (Secretaría de Ordenamiento Territorial y Obras Públicas), 2015. Programa de Ordenamiento Sustentable del Territorio del Estado de Tabasco. SOTOP, Villahermosa.

Teno, R., 2012. Resultados estadísticas de servicios Gaviotas, Brisas y Galaxia. UJAT, Unpubl. document.

Tonkiss, F., 2013. Cities by Design: The Social Life of Urban Form. Polity Press, Cambridge.

Walker, G., 2009. Beyond distribution and proximity: exploring the multiple spatialities of environmental justice. Antipode 41 (4), 614-636.

Walker, G., 2012. Environmental Justice: Concepts, Evidence and Politics. Routledge, London.

Wayessa, G., Nygren, A., 2016. Whose decisions, whose livelihoods? Resettlement and environmental justice in Ethiopia. Society \& Natural Resources 29 (4), 387-402.

Whitson, R., 2011. Negotiating place and value: geographies of waste and scavenging in Buenos Aires. Antipode 43 (4), 1404-1433. 